\title{
PEMBERDAYAAN USAHA KREATIF DENGAN MANAJEMEN KEUANGAN UNTUK MEMAKSIMALKAN LABA DI RUMAH GEMILANG INDONESIA AL AZHAR, SAWANGAN DEPOK
}

\author{
Rissa Hanny, Ahmad Nurhadi, Nurismalatri, Yhonanda Harsono, \\ Juwita Ramadani Fitria \\ Program Studi Manajemen \\ Universitas Pamulang \\ Email : Rissa.Hanny@gmail.com
}

\begin{abstract}
This community service is entitled "Empowerment of Creative Businesses with Financial Management to Maximize Profits at Rumah Gemilang Indonesia Al Azhar, Sawangan Depok". The purpose of this service is to give guidance to students (participants) that they must become young people who have creativity in entrepreneurship, and empower creative businesses that are always innovating, in addition to providing knowledge to participants (students) about financial management methods that can provide maximum profit in entrepreneurship so that they can become successful entrepreneurs in the future. The method of implementing this service is carried out in a number of activities, namely the survey phase by visiting Gemilang Indonesia's House and then socializing there with the leadership of Gemilang's house after that compiling various things to be conveyed during the service activities to be carried out which include: preparation of material to be given, preparation of schedules provision of material, division of tasks of the devotion team and surveys to the service location. The socialization phase is before the community service activities are carried out first, the socialization phase is to make a friendship with the leaders of Rumah Gemilang Indonesia, conveying the aims and objectives of this service. At this stage also carried out the fabric of cooperation and determine the schedule of service activities. The implementing team of community service activities is 9 lecturers at the Faculty of Economics majoring in management. The dedication team provided material on Creative Business Empowerment with Financial Management to Maximize Profit at Gemilang Indonesia Al Alzhar House, Sawangan Depok, conducted by lecturers from the Faculty of Economics, Management Study Program at the University of Pamulang. The conclusion of this dedication is that participants initially did not understand how to be able to create creative businesses and implement financial management so that their
\end{abstract}


businesses could obtain maximum profits. Our hope with this dedication can open insight from female and female students who will face the world of society. The material we provide is learning and practice in the field of management, especially good financial management as well as study material and input for these students to be able to implement it in daily life, so that it can help and improve scientific levels and be inspired in making home-based businesses that are will be very useful in their lives in the future.

Keywords: Creative Business, Financial Management, Profit.

\begin{abstract}
Abstrak
Pengabdian masyarakat ini berjudul "Pemberdayaan Usaha Kreatif dengan Manajemen Keuangan untuk Memaksimalkan Laba di Rumah Gemilang Indonesia Al Azhar, Sawangan Depok". Tujuan pengabdian ini adalah untuk memberikan pengarahan kepada santri (peserta) bahwa mereka harus menjadi generasi muda yang memiliki kreatifitas dalam berwirausaha, dan melakukan pemberdayaan usaha kreatif yang selalu berinovasi, selain itu memberikan pengetahuan kepada para peserta (santri) tentang metode manajemen keuangan yang bisa memberikan keuntungan yag maksimal dalam berwirausaha agar mereka bisa menjadi wirausahawan yang sukses ke depan. Metode pelaksanaan pengabdian ini dilakukan dalam beberapa kegiatan yaitu tahap survei dengan berkunjung ke Rumah Gemilang Indonesia lalu sosialisasi disana dengan pimpinan rumah Gemilang setelah itu menyusun berbagai hal yang akan disampaikan pada saat kegiatan pengabdian yang akan dilakukan yang meliputi: penyusunan materi yang akan diberikan, penyusunan jadwal pemberian materi, pembagian tugas tim pengabdian dan survei ke lokasi pengabdian. Tahap sosialisasi yaitu sebelum kegiatan pengabdian dilaksanakan terlebih dahulu dilakukan tahap sosialisasi yaitu melakukan silaturahmi dengan pimpinan Rumah Gemilang Indonesia, menyampaikan maksud dan tujuan pengabdian ini. Pada tahap ini juga dilakukan jalinan kerjasama dan menentukan jadwal kegiatan pengabdian. Tim pelaksana kegiatan pengabdian pada masyarakat adalah dosen Fakultas Ekonomi jurusan manajemen sebanyak 9 orang. Tim pengabdian memberikan materi tentang Pemberdayaan Usaha Kreatif dengan Manajemen Keuangan untuk Memaksimalkan Laba di Rumah Gemilang Indonesia Al Azhar, Sawangan Depok yang dilakukan oleh dosen dosen dari Fakultas Ekonomi Program Studi Manajemen Universitas Pamulang. Kesimpulan dari pengabdian ini adalah Peserta awalnya kurang
\end{abstract}


memahami bagaimana cara agar bisa menciptakan usaha kreatif dan menerapkan manajemen keuangan agar usaha mereka bisa meperolah laba yang maksimal. Harapan kami dengan pengabdian ini dapat membuka wawasan dari santriwan dan santriwati yang akan menghadapi dunia masyarakat. Materi yang kami berikan yaitu pembelajaran dan praktek dalam bidang manajemen khususnya manajemen keuangan yang baik sekaligus bahan kajian dan masukan bagi para santriwan/santriwati tersebut untuk dapat mengimplementasikannya dalam kehidupan sehari-hari, sehingga dapat membantu dan meningkatkan tingkat keilmuan dan terinspirasi dalam membuat usaha rumahan yang akan sangat bermanfaat dalam kehidupan mereka pada masa yang akan datang.

Kata Kunci: Usaha Kreatif, Manajeman Keuangan, Laba.

\section{A. PENDAHULUAN}

Rumah Gemilang Indonesia (RGI), berdiri di lahan wakaf seorang donatur seluas 1.600 meter persegi di Kampung Kebon Kopi, Kelurahan Pengasinan, Kecamatan Sawangan, Kota Depok. RGI, sebuah unit program pemberdayaan dan pusat pelatihan (empowering and training center) di bawah direktorat Program Al-Azhar Peduli Ummat. Secara resmi, RGI mulai beroperasi sejak 1 Juni 2009 dengan melakukan sosialisasi kepada masyarakat di wilayah Kec. Sawangan Kota Depok. Sebagai bagian dari program pemberdayaan Al-Azhar Peduli Ummat, RGI mengadopsi platform pesantren, tapi fokus pada penyelenggaraan pendidikan nonformal dalam kemasan short course (kursus singkat). Perpaduan ini bertujuan agar para peserta pelatihan RGI tidak hanya menyerap pengetahuan dan keterampilan unggul yang menjadi pondasi masa depan mereka, tapi juga memiliki pengetahuan dan dasar akidah iman yang baik.

Bukan perkara mudah mewujudkan gambar rencana menjadi bangunan fungsional. Estimasi biaya pembangunan mencapai angka Rp 3 miliar. Belum termasuk biaya untuk fasilitas dan operasional. Al-Azhar Peduli Ummat pun mengundang donatur yang peduli terhadap pendidikan bagi yatim dan dhuafa untuk berpartisipasi dalam pembangunan RGI. Caranya, delapan ruang kelas di lantai dua dan empat kelas di lantai satu, dilelang dalam akad wakaf tunai masing-masing seharga Rp 100 juta. Selain mendapatkan sertifikat, pemenang lelang berhak memberikan nama ruang, sesuai yang dikehendaki. Hall dan perpustakaan di lantai 1, juga dilelang dengan nilai masing-masing Rp 200 juta. Kini, bangunan megah dengan fasilitas pelatihan yang menuju sempurna itu, sudah dimanfaatkan sebagai training center untuk remaja usia produktif yang putus sekolah maupun yang tak mampu melanjutkan ke jenjang tinggi. Komunitas masyarakat dan pesantren juga memetik manfaat dari keberadaan RGI ini. Mereka secara gratis dapat belajar pengetahuan dan keterampilan yang selama ini hanya dapat dinikmati kalangan ekonomi mampu.

Dalam peran empowering, RGI disiapkan sebagai pusat pemberdayaan dan entrepreneur. Seluruh produk yang dihasilkan RGI, disiapkan sebagai produk bisnis yang akan menopang operasional RGI dan menjadi wahana bagi para peserta RGI memasarkan 
hasil karyanya. Tujuannya meningkatkan taraf ekonomi alumni RGI untuk mendapatkan kehidupan lebih baik, mandiri, berjiwa sosial, dan memiliki nilai-nilai agama dengan baik. Karena hal itulah makanya, kami sebagai bagian dari melaksanakan Tri Dharma Perguruan Tinggi Universitas Pamulang (UNPAM) berkewajiban untuk bisa memberikan masukan dan arahan dalam menerapkan Tugas pendidikan dengan cara mengupayakan agar anak bisa mengenal potensi dirinya, sedangkan pendidikan berperan memberikan fasilitas agar mereka dapat mengembangkan potensinya, baik di bidang akademik maupun potensi non-akademik. Mengenai hal tersebut bagaimana upaya pendidikan dalam membangun generasi muda yang kreatif dalam berwirausaha.

Berwirausaha yang kreatif dapat membantu generasi muda dalam menciptakan lapangan pekerjaan dan menghasilan pendapatan sendiri tanpa bergantung pada sebuah perusahaan, agar tercipta usaha yang kreatif masyarakat harus mempunyai keuntungan usaha yang maksimal dan baik sehingga dapat terbentuk usaha yang sehat dan berpotensi tinggi. Masalah yang banyak dihadapi di Indonesia adalah banyaknya usaha yang gulung tikar akibat laba yang minim bahkan bangkrut karena modal sudah habis. Karena minimnya pengetahuan dan pemahaman masyarakat mengenai metode manajemen keuangan yang baik, terutama pengusaha yang hanya mengerti dalam berbisnis tetapi kurang memahami metode perhitungan laba dengan manajemen keuangan yang baik dan terstruktur, terutama di usaha kecil menengah yang hanya memahami caranya berwirausaha dan berjualan yang baik, tetapi ilmu dalam perhitungan keuntungan masih menggunakan metode manual atau alami, dimana jika penghasilan tinggi maka laba yang diperoleh akan banyak tanpa memahami metode manajemen keuangan yang baik dalam berwirausaha.

Rendahnya pemahaman ilmu manajemen keuangan yang dimiliki oleh para generasi muda merupakan aspek penting yang harus dibenahi agar nantinya mereka dapat membentuk usaha yang kreatif dengan hasil yang memuaskan. Ilmu manajemen keuangan sifatnya sangat akademik kelihatannya, tetapi jika kita bisa menciptakan pemahaman yang ringan dan mudah di cerna oleh masyarakat terutama generasi muda, maka dapat memberikan pengetahuan baru yang sangat bermanfaat dan menunjang usaha mereka dalam berwirausaha yang baik, kreatif serta dapat menguntungkan. Sasaran yang ingin di capai melalui program ini adalah agar para peserta (santri) lebih memahami ilmu pengetahuan tentang manajemen keuangan yang baik terutama erat hubungannya dalam menciptakan usaha yang kreatif dengan laba yang maksimal. Jangan hanya mengerti caranya berwirausaha saja tetapi juga memahami perhitungan keuangan dalam berbisnis. Untuk menciptakan generasi muda yang kreatif dan mandiri maka diperlukan juga ilmu yang berkompetensi di bidangnya sehingga mampu menunjang kegiatan berwirausaha yang tidak hanya kreatif saja tetapi juga menghasilkan keuntungan yang baik dan sehat.

\section{B. METODE PELAKSANAAN KEGIATAN}

Metode pelaksanaan pengabdian dilakukan dalam beberapa kegiatan yaitu tahap survei lalu sosialisasi setelah itu menyusun berbagai hal yang akan disampaikan pada saat kegiatan pengabdian yang meliputi: penyusunan materi yang akan diberikan, jadwal pemberian materi, pembagian tugas dan survei. Tahap sosialisasi yaitu sebelum kegiatan pengabdian dilaksanakan terlebih dahulu dilakukan tahap sosialisasi yaitu melakukan silaturahmi dengan pimpinan Rumah Gemilang Indonesia, menyampaikan maksud dan tujuan pengabdian ini. 
Pada tahap ini juga dilakukan jalinan kerjasama dan menentukan jadwal kegiatan pengabdian. Tim pelaksana kegiatan pengabdian pada masyarakat adalah dosen Fakultas Ekonomi jurusan manajemen sebanyak 9 orang. Tim pengabdian memberikan materi tentang pemberdayaan usaha kreatif dengan manajemen keuangan untuk memaksimalkan laba di Rumah Gemilang Indonesia Al Azhar, Sawangan Depok yang dilakukan oleh dosen dosen dari Fakultas Ekonomi Program Studi Manajemen Universitas Pamulang.

\section{HASIL DAN PEMBAHASAN}

Pengabdian Masyarakat (LPPM) Universitas Pamulang yang dilakukan oleh dosendosen program studi Manajemen berjalan dengan lancar dan mendapat sambutan hangat dari tempat pelaksanaan kegiatan ini di Rumah Gemilang Indonesia Al Azhar, yang bertempat di Sawangan Depok.

\section{KESIMPULAN DAN SARAN}

\section{Kesimpulan}

Peserta awalnya kurang memahami bagaimana cara agar bisa menciptakan usaha kreatif dan menerapkan manajemen keuangan agar usaha mereka bisa meperolah laba yang maksimal.

\section{Saran}

Harapan kami dengan pengabdian ini dapat membuka wawasan dari santriwan dan santriwati yang akan menghadapi dunia masyarakat khususnya agar lebih kreatif dalam usaha di masa depan

\section{DAFTAR PUSTAKA}

Ferdiansyah. (2016). Analisis Pengaruh Citra Merek, Lokasi Dan Promosi Terhadap Keputusan Orang Tua Murid Memilih Jasa Pendidikan MTs DI KKM MTsN Pamulang. Universitas Pamulang.

Hanny, R. (2015). Pengaruh Strategi Promosi, Komunikasi dan Kepercayaan dalam Menjalanlan Ecommerce Nerworking Business di Indonesia. Tesis: Universitas Pamulang.

Kotler, P., dan Keller, K. L. (2012). Marketting Management edisi 14, Global Editon. Pearson Prentice Hall.

Solihin, D. (2020), Faktor-Faktor Yang Mempengaruhi Kinerja Pemasaran Pada PT Prima Ufuk Semesta (Studi Empiris Pada Outlet Rekanan Pt. Prima Ufuk Semesta Di Wilayah Jabodetabek), Jurnal Semarak, Vol. 3. No. 1.

Solihin, D. (2020), Pengaruh Kualitas Pelayanan, Harga, Dan Promosi Terhadap Keputusan Pelanggan Dalam Memilih Klub Basket Satria Indonesia Tangerang Selatan, Jurnal Pemasaran Kompetitif, Vol. 3, No. 3. 